\title{
Effect of Different Growing Substrates on Physiological Processes, Productivity and Quality of Tomato in Soilless Culture
}

\author{
Julè Jankauskienè, Aušra Brazaitytè and \\ Pranas Viškelis \\ Additional information is available at the end of the chapter \\ http://dx.doi.org/10.5772/59547
}

\section{Introduction}

The most innovative technology of plants growing in greenhouses is growing plants in mineral substrates such as rockwool, vermiculite, perlite, zeolite, ceramsite and others. The origin of substrates is different, some of them are of natural origin while others are produced artificially [1-3]. They also differ in their physical, chemical, and biological properties. Therefore, substrate selection is one of the most important factors affecting plant growth and development in the greenhouse and influencing vegetable quality.

Vegetable-growing rockwool is a widely used substrate for growing of tomatoes and cucumbers under commercial production system. However, one of the biggest disadvantages of this substrate is the need to utilize it. Currently for growing vegetables' different natural substrates are also used and one of these is coconut fiber [4-7]. Substrates of coconut fiber are produced in most countries (like Polland, Netherlands, Belgium, Chezch Republic). Current recycling technologies allow to produce different products in its quality which have its advantages compared to other substrates which are used in greenhouses for growing vegetable [8]. Ready to use coconut fiber substrate may look like dry brick, non-pressed pack as well as blocks' shape. Blocks of coconut fiber are widely used in floriculture, especially for growing roses and gerbera $[9,10]$. Coconut fiber is a absolutely $(100 \%)$ organic substrate which is made from recycling the shells of coconuts. It is inert substrate as it does not dissolve upon utilization, size does not change but restrains huge amount of water (more than rockwool). Coconut fiber has other properties such as it is typical to absorb warmth, do not get salty, and it has no pathogens and seeds of weeds $[6,11,12]$. Substrate of coconut fiber is an alternative for 
rockwool, no problems appears after utilization. This substrate also has its advantages over rockwool for example; structure of coconut fiber does not change for several years due to its high lignin content. The same structure lasts for 3-4 years. In this way, substrate may be used for few years [8]. Results of last investigations showed that coconut fiber were sufficient substrates for growing of some plants especially for vegetables and grower use these materials as growing media in greenhouse cultures [13]. Albaho and others [14] argued that coconut fiber and its mixes with other substrates could be used as alternative substrate for tomato growing.

Peat and their mixes with perlite, vermiculite, zeolite are the most widely used substrates in greenhouse. In most countries there are analyzed features of zeolite and possibilities to use it for growing of vegetables [15-17]. Zeolites are hydrated crystalline aluminosilicate minerals of natural occurence, structured in rigid third dimension net. This is ecologically clean, inert and non-toxic substance. It is characterized by ion exchange and adsorption features $[18,19]$. According to Russian scientist, one of the most promising fields of plant-growing is use of natural zeolite as a substrate for seedlings and vegetables to grow [20,21]. There are different reports related to use of zeolite as substrates in hydroponic culture. Technologies of growing cucumbers, tomatoes and green vegetables in zeolite were created in Russia [17,22]. There were also analyzed opportunities how zeolite as a substrate and its mixes with peat could be used in greenhouses [16,19]. It was found that using zeolite less nutrients is missed, efficiency of mineral fertilizer increases. There were analyzed options of using zeolite to grow seddlings of vegetables as well as potted plants [23-25]. Gül and others [26] concluded that the use of zeolite led to increased lettuce plant growth. Most scientific researches reveal the effect of substrates for vegetables productivity [27-29]. Gruda [30] states that it is possible to improve the quality of fruit if suitable substrate is chosen. Other researches show effect of substrates and its mixes for vegetable quality $[23,29,31-33]$.

The aim of this study was to estimate of rockwool and coconut fiber substrates on productivity and quality of tomato hybrids 'Raissa' and 'Admiro'. In addition to establish the optimal amount of zeolite in peat substrate and to evaluate the influence of zeolite-peat mixes on productivity and quality of tomato hybrid 'Ronaldo'.

\section{Materials and methods}

\subsection{Growing conditions}

1. The investigations were carried out at the Institute of Horticulture, in the Multi Rovero 640 TR ("Rovero", the Netherlands) greenhouse covered with a double polymer film. The tomatoes were sown at the beginning of February and the seedlings were grown in rockwool growing cubes on the shelvings in a heated nursery and lighted additionally by high pressure sodium lamps (Philips SON-T Agro). At the beginning of March the seedlings were transplanted in the greenhouse (Figure 1). The plant density in the greenhouse was 2.5 plants per $\mathrm{m}^{-2}$. The end of tomato vegetation was the middle of October. Two factors were investigated: factor A - tomato hybrids: $\mathrm{a}_{0}$ - 'Raissa', $\mathrm{a}_{1}$ - 
'Admiro', factor B - substrate: $\mathrm{b}_{0}$ - rockwool, $\mathrm{b}_{1}$ - coconut fiber. Plot area $-8 \mathrm{~m}^{2}$. Four replications were done in a randomized block design.

2. The investigations were carried out at the Institute of Horticulture, in the Multispan 9.60 SR ("Richel", France) greenhouse covered with a double polymer film. The tomato seedlings were grown in polymer pots filled with peat substrate (Profi 1, Durpeta, Lithuania) ( $\mathrm{pH} 5-6$ ) on the shelvings in a heated nursery and lighted additionally by high pressure sodium lamps (Philips SON-T Agro). In the greenhouse the plants were grown in 251 peat bags ( 1 bag -2 plants) (Figure 2 ). The plant density was 2.5 plants per $\mathrm{m}^{-2}$. The start of tomato vegetation was the beginning of February and the end was the middle of October. The investigation object was hybrid 'Ronaldo'. Different substrates were investigated: $a_{0}$ - peat, $a_{1}$ - peat + zeolite $(15 \%), a_{2}$ - peat + zeolite $(30 \%)$. Plot area -9.6 $\mathrm{m}^{2}$. Three replications were done in a randomized block design.

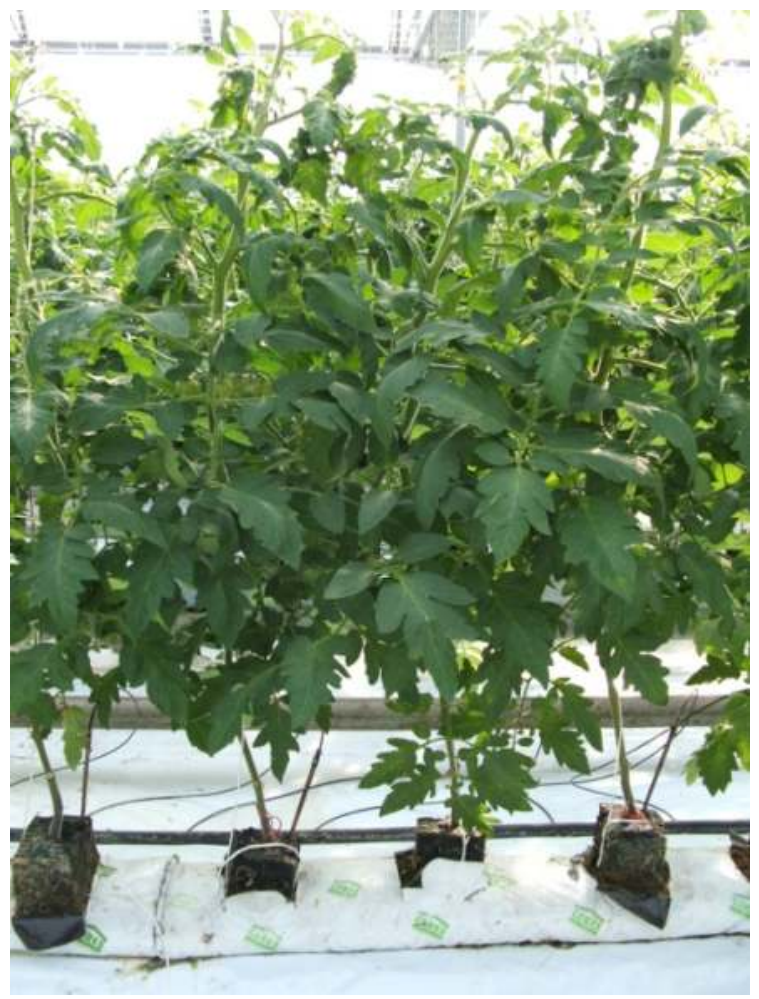

Figure 1. Tomato in coconut fiber substrate 


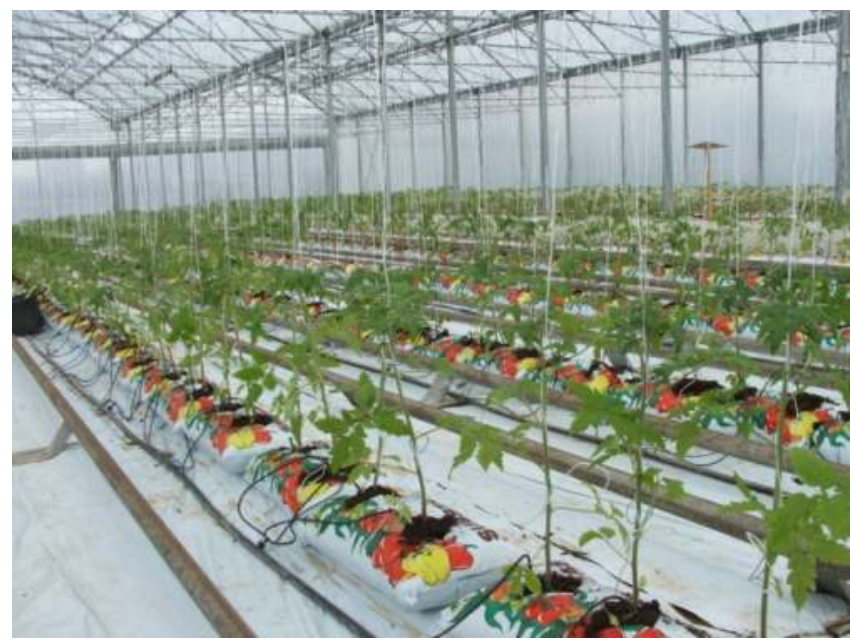

Figure 2. Tomato in peat bags

\subsection{Cultivation procedure}

In both greenhouses the tomatoes were grown using drip irrigation and fertilized with "Nutrifol" (green, NPK 8-11-35 plus microelements - S, MgO, Mn, B, Zn, Cu, Co, Mo, Fe) (first half of the vegetation), "Nutrifol" (brown, NPK 14-10-25 plus microelements - S, MgO, Mn, B, $\mathrm{Zn}, \mathrm{Cu}, \mathrm{Co}, \mathrm{Mo}, \mathrm{Fe}$ ) (second half of vegetation), magnesium sulphate, calcium and ammonium nitrate fertilizers. There was prepared solution, which was diluted with water in a ratio of 1 : 100 , and plants were fertilized taking into the account the growth stage (4-15 times a day). Nitric acid was used for water acidification. The concentration of salts in the nutrient solution was EC 2.6-3.0, acidity - $\mathrm{pH}$ 5.5-5.8.

\subsection{Biometric measurements}

During the investigation the plant height was measured at three times during vegetative growth each 10 days after transplanting the seedlings in the greenhouse and the leaves were also counted.

\subsection{Determination of photosynthetic pigments and dry matter}

For sample preparation of photosynthetic pigment $0.2 \mathrm{~g}$ of fresh weight were ground with 0.5 $\mathrm{g} \mathrm{CaCO}_{3}$ (Sigma-Aldrich, Germany) and extracted in 100\% acetone (Merck, Germany), according to Vetsthtein [34]. Spectrophotometric analysis (spectrophotometer Genesys 6, USA) and quantification of total chlorophylls $a, b$ and carotenoids were performed at $440.5 \mathrm{~nm}, 662$ $\mathrm{nm}$, and $644 \mathrm{~nm}$ wavelengths, respectively. The measurements were performed in four replicates $(n=4)$. The fully formed leaves were analyzed. 
To determine dry weight tomato leaves and fruits were dried in a drying oven (Venticell,MBT, Czech Republik) at $105{ }^{\circ} \mathrm{C}$ for $24 \mathrm{~h}$. The content of dry matter and photosynthetic pigments in leaves were established at three times during entire growth phase, such as measurement I - at the beginning of flowering, measurement II - at the start of yielding, measurement III - at full yielding.

\subsection{Phytomonitoring investigations}

The phytomonitoring investigations were carried out on the tomatoes grown in different substrates. The physiological processes of tomato 'Raissa' $F_{1}$ were investigated using a phytometric system "LPS-03" created by "PthyTech Ltd."(Figure 3). The following sensors were used for the investigations such as sap water flow, stem diameter evolution, fruit diameter evolution and leaf-air temperature differences (Figure 4). The data of these sensors reflect the plant response to various growing conditions best. In addition, microclimate parameter sensors (those of air temperature and total irradiance) were used. The sensors were fixed according to "PhyTech Ltd." recommendations [35,36]. The sensors of stem diameter evolution, stem flux rate and leaf-air temperature were used as indirect indicators of transpiration. The plants were measured for five days.

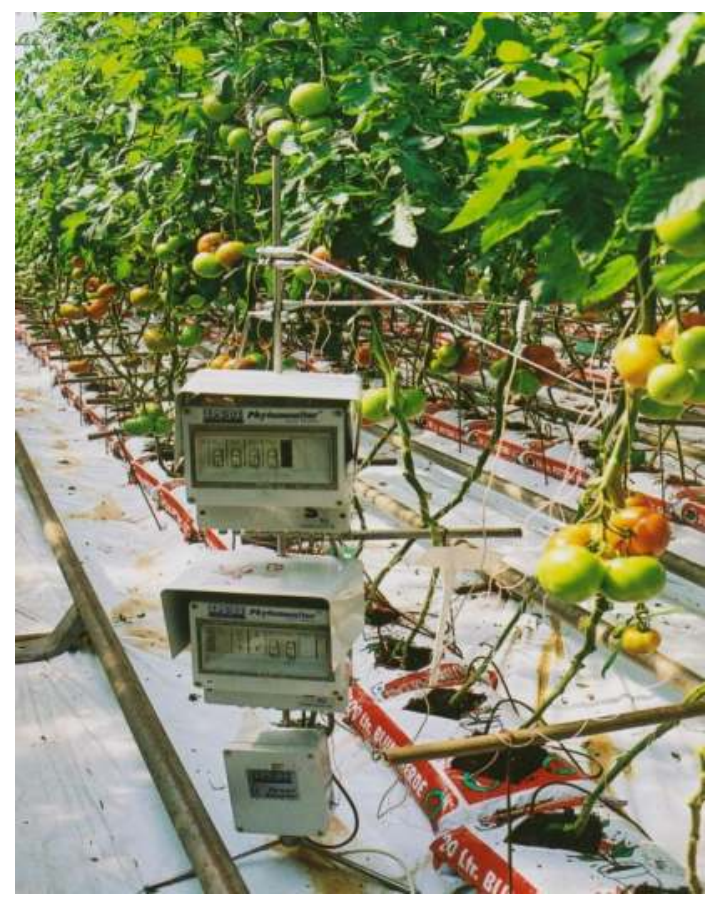

Figure 3. The phytometric system LPS-03 


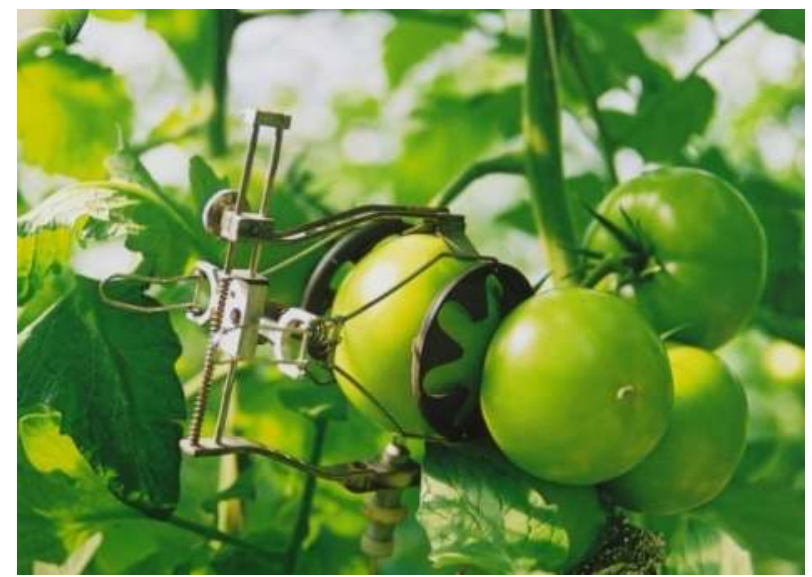

Figure 4. Fruit diameter sensor

\subsection{Yielding of plants}

The tomato yield was recorded at every harvest. Tomato fruits were harvested three times a week, next they were separated into marketable and non-marketable ones. Total yield were calculated by aggregating each harvest.

\subsection{Biochemical analysis}

The biochemical composition of tomato fruits was investigated at the Laboratory of Biochemistry and Technology, Institute of Horticulture. The following methods were applied in establishing the composition: sugars - by AOAC method [37], carotenoids - spectrophotometrically by Genesys10 UV/VIS spectrophotometer (Thermo Spectronic, Rochester, USA) [38], nitrates - by potentiometrical method using an ion selective electrode [39]. The total soluble solids were determined by a digital refractometer (ATAGO PR-32, Atago Company, Japan). The dry matter content was determined by the air oven method after drying at $105^{\circ} \mathrm{C}$ in a Universal Oven ULE 500 (Memmert GmbH+Co. KG, Schwabach, Germany) to a constant weight [40]. Ascorbic acid content was measured by titration with 2.6-dichlorphenolindophenol sodium salt using chloroform for intensely coloured extracts [37]. Titrable acidity was measured by titrating $10 \mathrm{~g}$ of pulp that had been homogenised with $100 \mathrm{ml}$ distilled water. The initial $\mathrm{pH}$ of the sample was recorded before titration with $0.1 \mathrm{~N} \mathrm{NaOH}$ to final $\mathrm{pH}$ 8.2. The acidity was expressed as the percentage of citric acid equivalent to the quantity of $\mathrm{NaOH}$ used for the titration.

\subsection{Statistical analysis}

The data were analysed by ANOVA statistical package [41]. The Fisher's LSD was used to determine significant treatment effects. Statistical significance was evaluated at $\mathrm{p} \leq 0.05$. 


\section{Results}

\subsection{Effect of rockwool and coconut fiber substrates on productivity, physiological processes and quality of tomato}

During vegetation the tomato hybrids grown in different substrates grew and developed differently. The height and leaf number depended both on the substrate used and on the hybrid itself (Table 1). Tomatoes 'Raissa' $F_{1}$ grown in a coconut fiber substrate were 8.1-9.2\% higher (insignificant difference) compared with the plants grown in rockwool. Moreover, they had a larger number of leaves. The plants of hybrid 'Admiro' grown in the coconut fiber substrate were slightly lower during the first and the second measures taken (insignificant difference) compared with those grown in rockwool. During the third measure taking the height of this hybrid was equal in both substrates. The 'Admiro' plants grown in rockwool and coconut fiber had the same number of leaves.

\begin{tabular}{ccccccc}
\hline & \multicolumn{2}{c}{ Measurement I } & Measurement II & Measurement III \\
\cline { 2 - 6 } Substrate & $\begin{array}{c}\text { Plant height, } \\
\mathbf{c m}\end{array}$ & $\begin{array}{c}\text { Number of } \\
\text { leaves, unit }\end{array}$ & $\begin{array}{c}\text { Plant height, } \\
\text { cm }\end{array}$ & $\begin{array}{c}\text { Number of } \\
\text { leaves, unit }\end{array}$ & $\begin{array}{c}\text { Plant height, } \\
\text { cm }\end{array}$ & $\begin{array}{c}\text { Number of } \\
\text { leaves, unit }\end{array}$ \\
\hline Rockwool & 75.0 & 13.5 & 98.0 & 17.0 & 125.4 & 21.2 \\
\hline Coconut fiber & 81.1 & 14.4 & 107.1 & 18.1 & 136.9 & 21.7 \\
\hline LSD & 30.6 & 1.7 & 32.6 & 2.5 & 33.9 \\
\hline Rockwool & 79.5 & 14.6 & 103.4 & 17.7 & 130.8 & 21.2 \\
\hline Coconut fiber & 75.6 & 13.9 & 102.0 & 17.5 & 131.6 & 21.0 \\
\hline LSD $_{05}$ & 17.7 & 1.1 & 21.8 & 1.8 & 20.7 & 0.7 \\
\hline
\end{tabular}

Table 1. Effect of substrates on plant height and number of leaves of tomato during vegetation

The content of dry matter in the tomato leaves depended on the substrate (Figure 5). Both hybrids grown in rockwool accumulated a higher content of dry matter in their leaves during vegetation compared with those grown in coconut fiber. The content of dry matter in the leaves of tomatoes 'Raissa' $\mathrm{F}_{1}$ grown in rockwool was 2.6-8.1\% higher (depending on measuring) compared with those grown in the coconut fiber substrate (Figure 5 a). The content of dry matter in the leaves of tomato hybrid 'Admiro' grown in rockwool was higher in all measures taken (Figure $5 \mathrm{~b}$ ) (insignificant differences). 


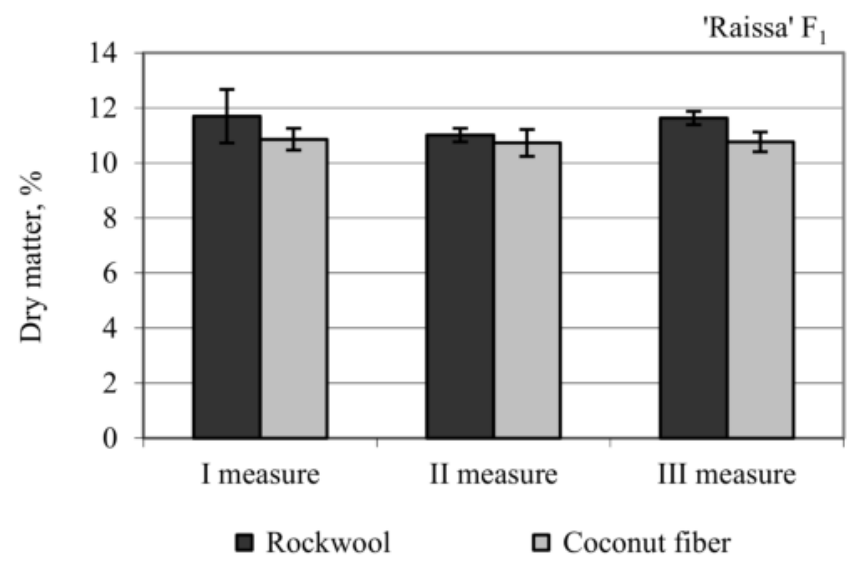

(a)

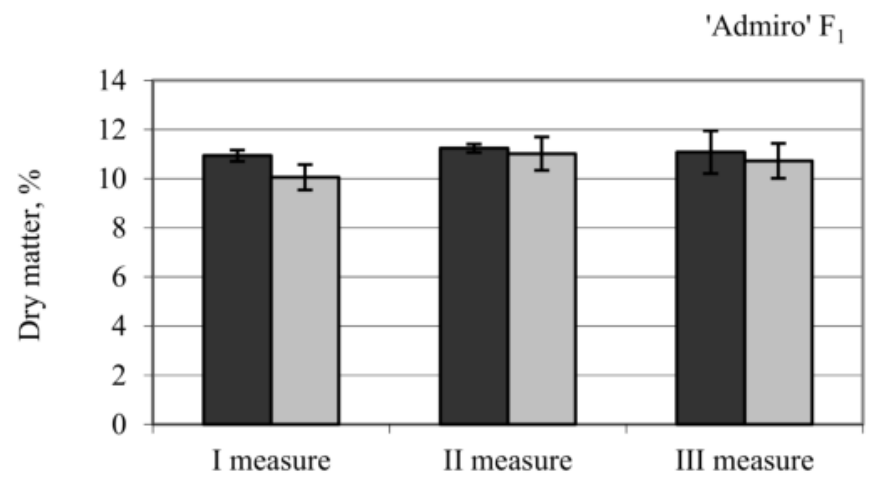

口 Rockwool

口Coconut fiber

(b)

Figure 5. Effect of substrates on dry matter content in leaves of tomatoes 'Raissa' $F_{1}$ (a) and 'Admiro' $F_{1}$ (b) during vegetation

The photosynthetic pigment content in the leaves of tomatoes depended on the substrate as well (Table 2). A higher amount of photosynthetic pigments was accumulated in the leaves of both hybrids grown in rockwool. The chlorophyll $\mathrm{a}+\mathrm{b}$ amount in the leaves of tomato hybrid 'Raissa' was higher by $3.4 \%$; in the case of tomato hybrid 'Admiro' it was $7.0 \%$ higher compared with the leaves of the tomatoes grown in the coconut fiber substrate. The chlorophyll $a$ to $b$ ratio in the leaves of both tomato hybrids grown in different substrates was almost similar. The content of carotenoids in the leaves of the tomatoes grown both in rockwool and coconut fiber was more or less the same during vegetation. A slightly lower content was accumulated in the tomatoes grown in the coconut fiber substrate. 


\begin{tabular}{|c|c|c|c|c|c|}
\hline \multirow[b]{2}{*}{ Substrate } & \multicolumn{5}{|c|}{ Photosynthetic pigment content and ratio, $\mathrm{mgg}^{-1}$ fresh mass } \\
\hline & chlorophyll a & chlorophyll b & chlorophyll $a+b$ & $\begin{array}{l}\text { chlorophyll } \\
\text { a to b ratio }\end{array}$ & carotenoids \\
\hline \multicolumn{6}{|c|}{ 'Raissa' $F_{1}$} \\
\hline Rockwool & 1.33 & 0.50 & 1.82 & 2.66 & 0.39 \\
\hline Coconut fiber & 1.28 & 0.48 & 1.76 & 2.67 & 0.37 \\
\hline $\mathrm{LSD}_{05}$ & 0.21 & 0.09 & 0.30 & 0.03 & 0.06 \\
\hline \multicolumn{6}{|c|}{ 'Admiro' $\mathrm{F}_{1}$} \\
\hline Rockwool & 1.34 & 0.50 & 1.84 & 2.68 & 0.39 \\
\hline Coconut fiber & 1.24 & 0.47 & 1.72 & 2.64 & 0.36 \\
\hline $\mathrm{LSD}_{05}$ & 0.06 & 0.05 & 0.11 & 0.14 & 0.01 \\
\hline
\end{tabular}

Table 2. Effect of substrates on photosynthetic pigment content and the chlorophyll a to b ratio in leaves of tomato

The intensity of photosynthesis depended on the hybrid of tomato (Figure 6). The photosynthesis intensity of tomato hybrid 'Admiro' was slightly higher compared with those grown in the coconut fiber substrate. The highest intensity of photosynthesis was established with tomato hybrid 'Raissa', when grown in the coconut fiber substrate.

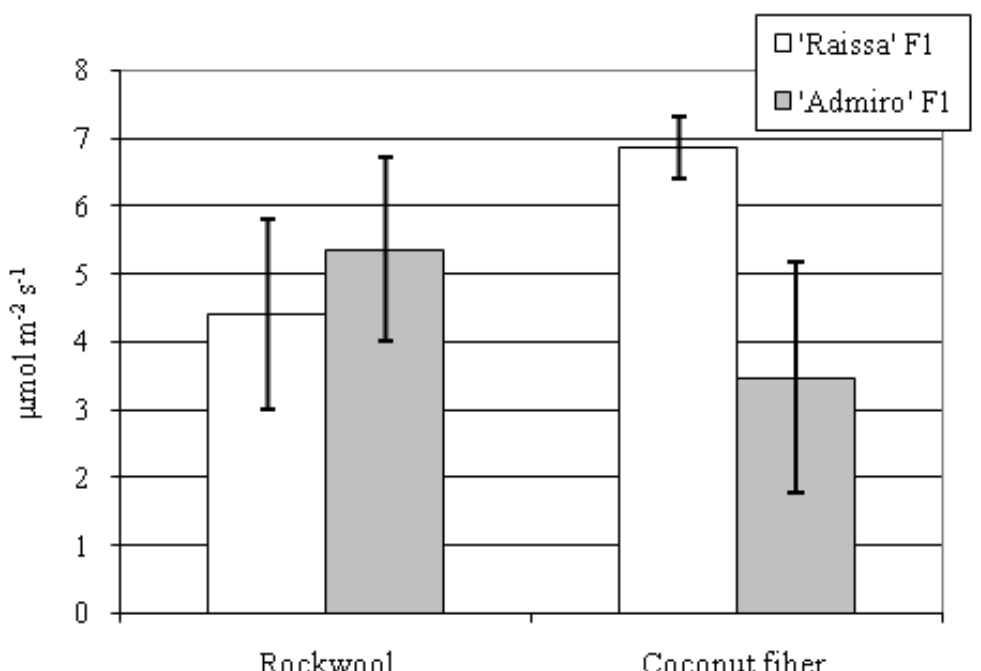

Figure 6. Effect of substrates on photosynthesis intensity of two tomato hybrids viz., 'Admiro' and 'Raissa'

The phytomonitoring investigations were carried out for five days. During the investigations the air temperature within the plant growing zone was about $25^{\circ} \mathrm{C}$ and judging from the total irradiance fluctuations the days were overcast with gaps in the clouds (Figure 7). According 
to the stem flux rate, stem diameter evolution and the difference in leaf-air temperature it is possible to assess the intensity of transpiration and the overall turnover of water in a plant (Figures 8 and 9). The variation of these indicators during 24 hours was similar both in the tomatoes grown in rockwool and in the coconut fiber substrate. In the middle of the day the stem flux rate increased, the stem diameter decreased and the leaf temperature was practically always lower than that of the air. Therefore, it can be proposed that the transpiration in tomatoes was very intensive and a low stem gain per 24 hours indicates that the plants were not supplied with water sufficiently. The tomatoes grown in coconut fiber demonstrated a higher leaf-air temperature difference compared with the tomatoes grown in rockwool. It can be proposed that the transpiration of the latter was less intensive. The more intensive transpiration in the tomatoes grown in coconut fiber had negative influence on fruit growth. Typically, fruits have to grow in a uniform fashion and this substrate practically stopped the daily growth and the growth returned to normal only in the second half of the night (Figure 10). The size increase of the tomatoes grown in rockwool was more uniform. Their growth slowed down in the middle of the day but it returned to normal again in the evening. It can be proposed that the tomatoes grown in coconut fiber substrate demonstrated a higher water demand compared with the tomatoes grown in rockwool.

The coconut fiber substrate had positive effect on the tomato yield (Figure 11). The yield of tomato hybrids 'Raissa' and 'Admiro' grown in coconut fiber was higher compared with those grown in rockwool (insignificant differences). The yield of tomato hybrid 'Admiro' was significantly higher compared with the yield of tomato hybrid 'Raissa' as there were more trusses on the plants formed and the number of fruits in a truss was higher. Somewhat higher early yield was obtained from the tomatoes grown in rockwool. The yield of non-marketable fruits from the tomatoes grown in different substrates was the same: it was $0.24 \mathrm{~kg} \mathrm{~m}^{-2}$ from tomato hybrid 'Raissa' in both substrates and $0.4 \mathrm{~kg} \mathrm{~m}^{-2}$ from tomato hybrid 'Admiro'.

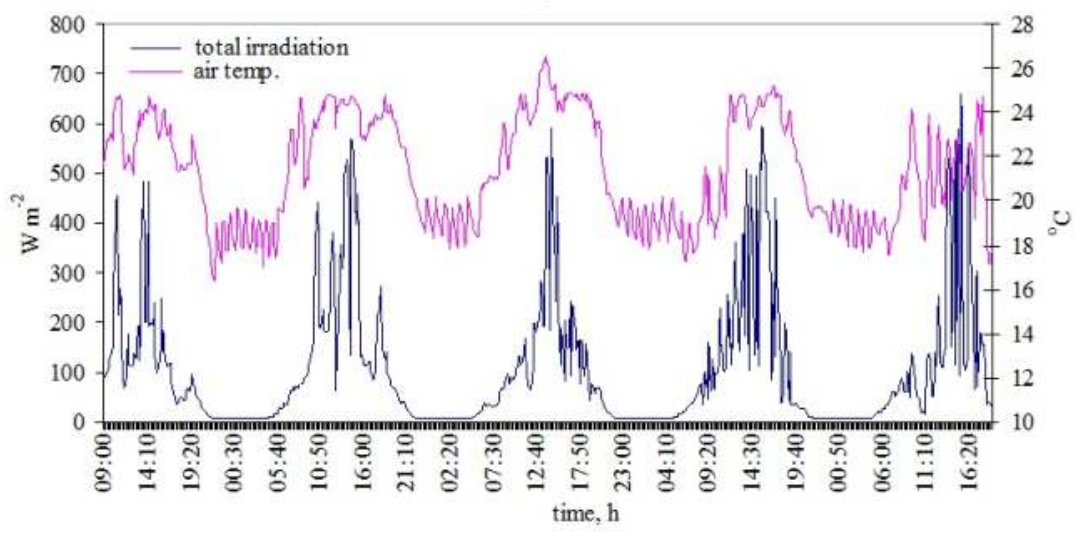

Figure 7. Changes in environmental parameters in greenhouses used for investigating effects of different substrates on the growth, physiological processes and quality of tomato 

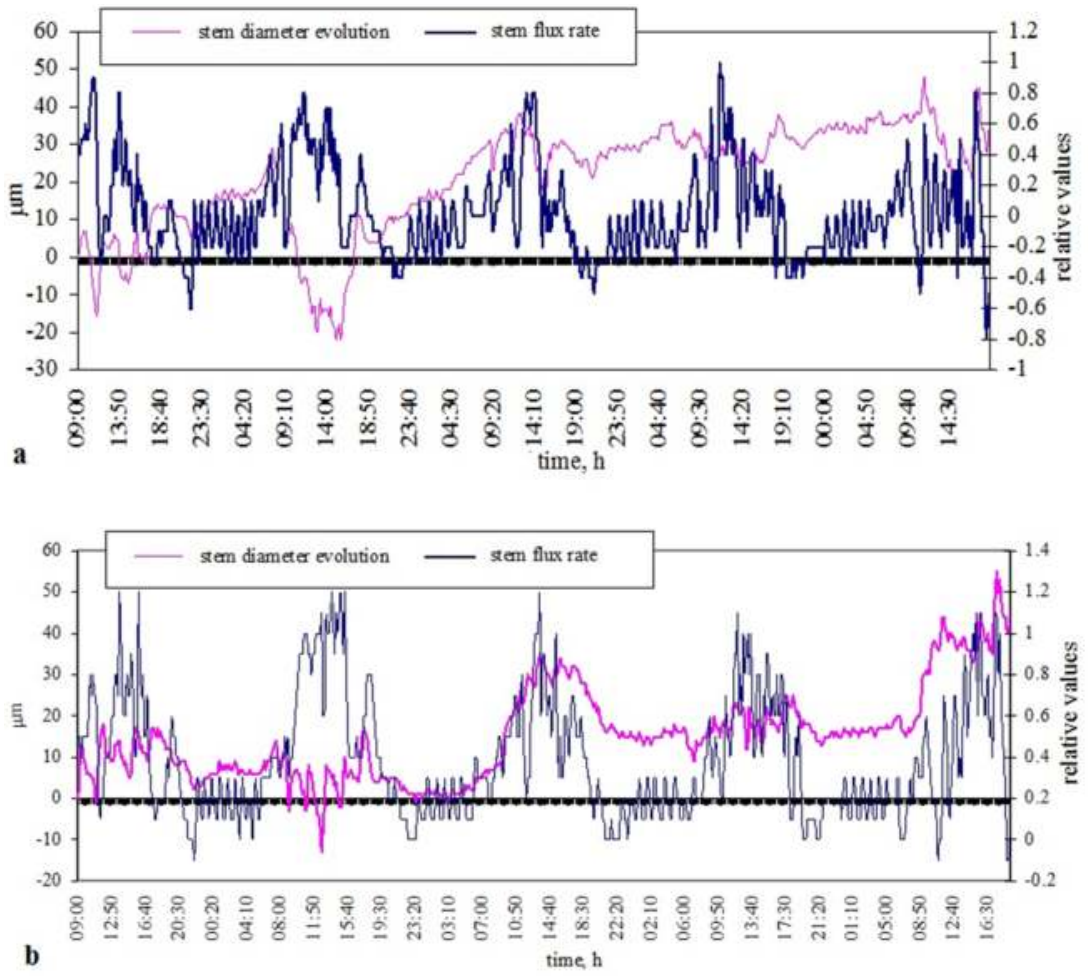

Figure 8. Stem flux rate and stem diameter evolution of tomato hybrid 'Raissa' $F_{1}$ grown in rockwool (a) and coconut fiber (b)

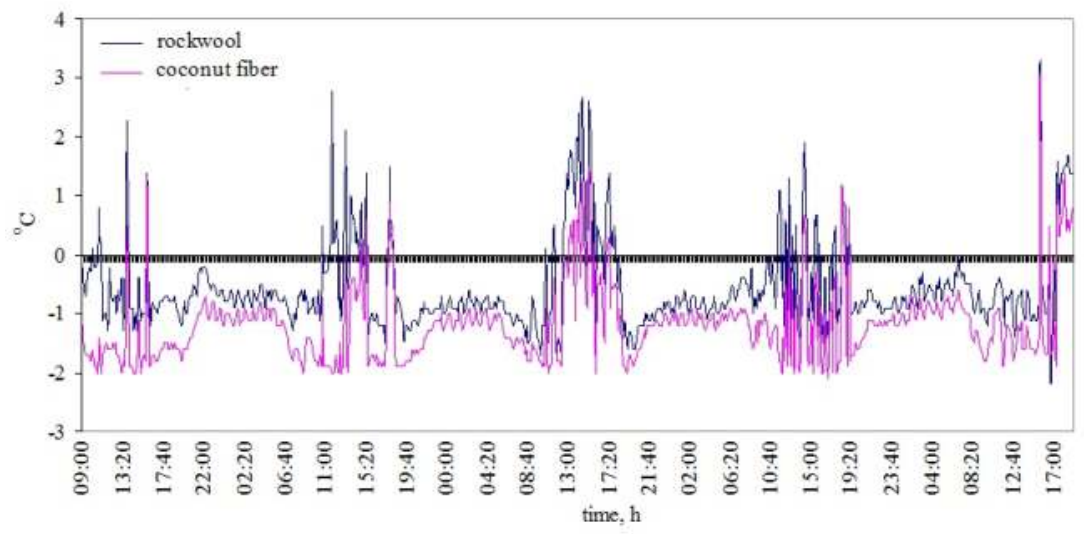

Figure 9. Leaf-air temperature differences of tomato hybrid 'Raissa' $F_{1}$ grown in rockwool and coconut fiber substrates 


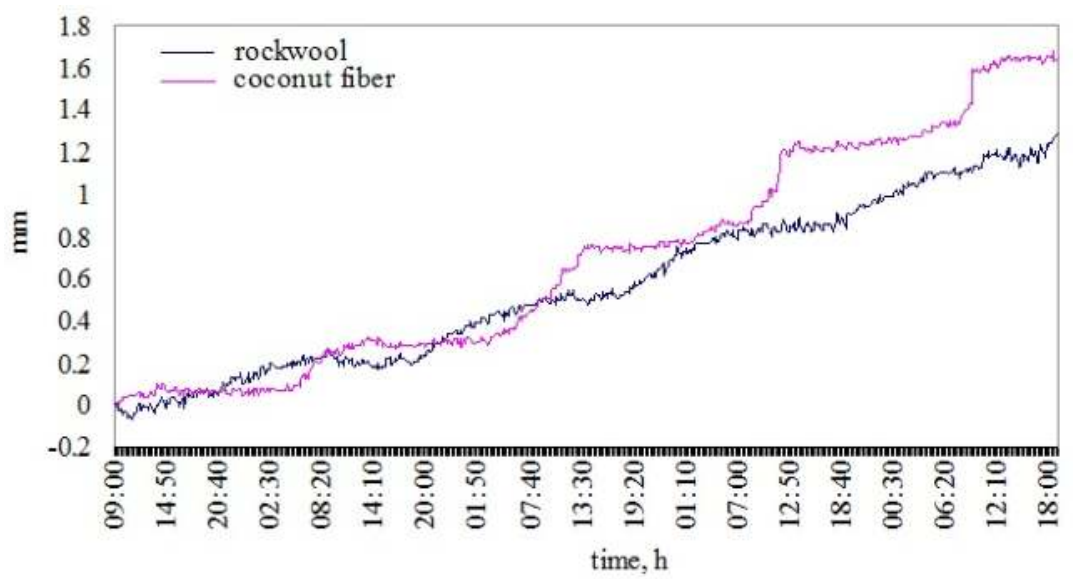

Figure 10. Fruit diameter evolution of tomato hybrid 'Raissa' $F_{1}$ grown in rockwool and coconut fiber substrates

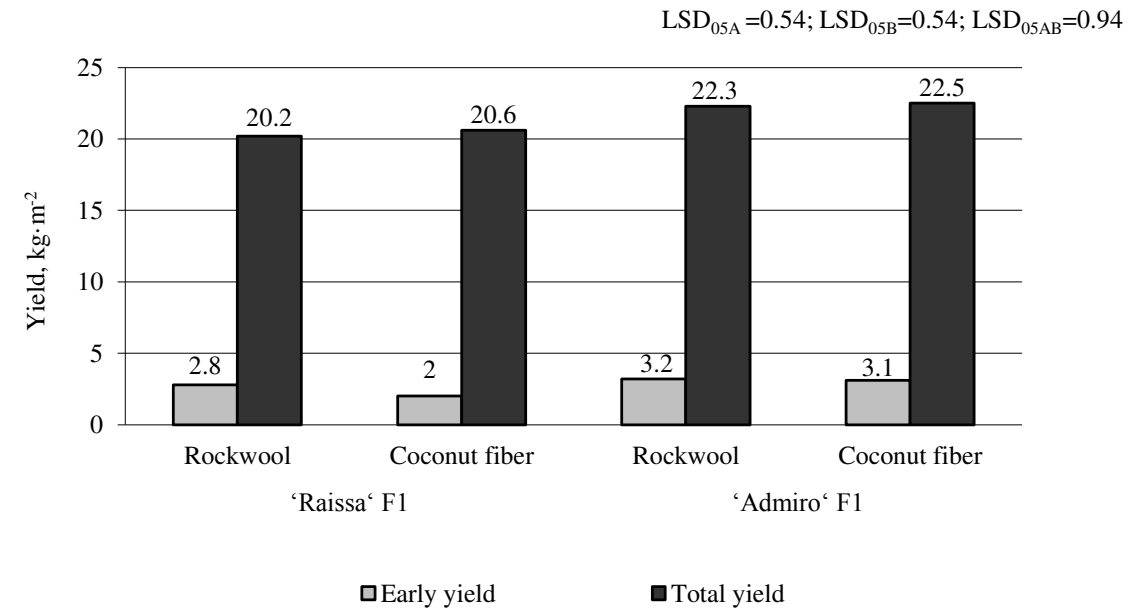

Figure 11. Effect of rockwool and coconut fiber on early and total yield of tomatoes plants grown under greenhouse condition

Tomato hybrid 'Raissa' formed 15 trusses both in rockwool and coconut fiber, however the number of fruits in a truss was different: the number was slightly higher in rockwool compared with coconut fiber (Table 3). Tomato hybrid 'Admiro' formed 15.5 trusses both in rockwool and coconut fiber and the number of fruits was the same. The substrate had no great influence on the average mass of a fruit. The fruit mass of the tomatoes grown in rockwool was slightly higher compared with those grown in coconut fiber. The fruits of tomato hybrid 'Raissa' were 
somewhat larger - the average mass of a fruit ranged from $137.1 \mathrm{~g}$ to $140.1 \mathrm{~g}$, and the average mass of 'Admiro' fruit was between $131.0 \mathrm{~g}$ and $135.4 \mathrm{~g}$.

\begin{tabular}{ccc}
\hline Substrate & Number of fruit in truss, unit & Average fruit mass, $\mathbf{g}$ \\
\hline Rockwool & 'Raissa' $\mathrm{F}_{1}$ & 140.1 \\
\hline Coconut fiber & 4.45 & 137.1 \\
\hline LSD $_{05}$ & 4.17 & 14.2 \\
\hline & 3.18 & 135.4 \\
\hline Rockwool & 'Admiro' $\mathrm{F}_{1}$ & 131.0 \\
\hline Coconut fiber & 4.73 & 10.8 \\
\hline LSD $_{05}$ & 4.93 & 1.91 \\
\hline
\end{tabular}

Table 3. Effect of rockwool and coconut fiber on fruit number and average mass of tomatoes plants grown under greenhouse condition

Growing of tomatoes in different substrates had influence on the biochemical composition of fruits (Table 4). Tomato hybrid 'Raissa' grown in rockwool accumulated a higher amount of sugars, dry soluble solids and dry matter (insignificant difference). The amount of ascorbic acid in the fruits of the tomatoes grown in coconut fiber was 1.1 times higher compared with the fruits of the tomatoes grown in rockwool (insignificant difference). Different substrates had influence on the amount of nitrates in tomato fruits: the amount was higher in the tomato fruits grown in rockwool (insignificant difference).

\begin{tabular}{|c|c|c|c|c|c|c|c|c|c|}
\hline \multirow{2}{*}{ Substrate } & \multicolumn{3}{|c|}{ Sugar, \% } & \multirow{2}{*}{$\begin{array}{c}\text { Dry } \\
\text { soluble } \\
\text { solids, \% }\end{array}$} & \multirow{2}{*}{$\begin{array}{c}\text { Ascorbic } \\
\text { acid, } \\
\text { mg\% }\end{array}$} & \multirow{2}{*}{$\begin{array}{l}\text { Titratable } \\
\text { acidity, \% }\end{array}$} & \multirow{2}{*}{$\begin{array}{c}\text { Carotene, } \\
\mathrm{mg} \%\end{array}$} & \multirow{2}{*}{$\begin{array}{c}\text { Dry } \\
\text { matter, \% }\end{array}$} & \multirow{2}{*}{$\begin{array}{l}\text { Nitrate, } \\
\text { mg kg }^{-1}\end{array}$} \\
\hline & inverted & saccharose & total & & & & & & \\
\hline \multicolumn{10}{|c|}{ 'Raissa' $\mathrm{F}_{1}$} \\
\hline Rockwool & 3.25 & 0.13 & 3.38 & 4.7 & 8.8 & 0.53 & 2.7 & 5.4 & 185 \\
\hline Coconut fiber & 2.12 & 1.14 & 3.26 & 4.5 & 9.5 & 0.52 & 2.6 & 5.0 & 172 \\
\hline $\mathrm{LSD}_{05}$ & 1.27 & 0.32 & 0.95 & 1.9 & 1.3 & 0.05 & 4.5 & 0.6 & 146.1 \\
\hline
\end{tabular}

Table 4. Effect of rockwool and coconut fiber on biochemical composition of tomato fruit

\subsection{Effect of peat and peat-zeolite substrates on productivity and quality of tomato}

The admixture of zeolite into a peat substrate had effect on the height of plants. The tomatoes grown in peat-zeolite substrates were lower compared with those grown in peat (Table 5). The tomatoes grown in the peat + zeolite (30\%) substrate were 3.1-5.9\% lower (depending on measuring) compared with the plants grown in the peat substrate. The tomatoes grown in the 
peat + zeolite $(15 \%)$ substrate were the lowest. A lower concentration of zeolite in peat had a greater effect on vegetative plant growth, i. e., the overground mass developed better. An asumption can be made that a greater concentration of zeolite had an effect of better root development but not on the overground plant section.

\begin{tabular}{llll}
\hline \multirow{2}{*}{ Substrate } & Plant height, cm & & \\
\cline { 2 - 4 } & Measurement I & Measurement II & Measurement III \\
\hline Peat & 49.6 & 71.0 & 101.6 \\
\hline Peat + zeolite (15\%) & 51.1 & 69.9 & 100.0 \\
\hline Peat + zeolite (30\%) & 48.1 & 67.0 & 96.9 \\
\hline LSD $_{05}$ & 8.4 & 6.3 & 6.9 \\
\hline
\end{tabular}

Table 5. Effect of peat and mixture of peat and zeolite substrates on tomato plant height during vegetation

At the beginning of vegetation the amount of dry matter in the leaves of the tomatoes grown in peat was higher compared with those grown in peat and zeolite substrates (Table 6). It was 5.3-8.2\% more (Measurement I and II, respectively) compared with the leaves of the tomatoes grown in the peat + zeolite (15\%) substrate and 1.1-11.6 \% more (Measurement I and II, respectively) compared with the leaves of the tomatoes grown in the peat + zeolite $(30 \%)$ substrate (insignificant differences). During the Measurement III it was established that the highest amount of dry matter in leaves was accumulated by the tomatoes grown in the peat + zeolite (30\%) substrate. The amount was 7.5\% higher compared with the leaves of the tomatoes grown in peat and $11.1 \%$ higher compared with the leaves of the tomatoes grown in the peat + zeolite (15\%) substrate (significant difference). During the entire vegetation the lowest amount of dry matter was accumulated in leaves of the tomatoes grown in the peat + zeolite $(15 \%)$ substrate.

The content of dry matter in the fruits of the tomatoes grown in different substrates during vegetation was different. The lowest amount of dry matter in the fruits was demonstrated by the tomatoes grown in the peat + zeolite $(15 \%)$ substrate. The average data of three measures revealed that the highest amount of dry matter in fruits was accumulated by the tomatoes grown in the peat + zeolite (30\%) substrate and it amounted to $6.4 \%$.

\begin{tabular}{lllllll}
\hline \multirow{2}{*}{ Substrate } & \multicolumn{2}{l}{ Measurement I } & \multicolumn{2}{l}{ Measurement II } & \multicolumn{2}{l}{ Measurement III } \\
\cline { 2 - 7 } & leaves & fruit & leaves & fruit & leaves & fruit \\
\hline Peat & 11.08 & 5.95 & 10.31 & 5.95 & 10.06 & 6.97 \\
\hline Peat + zeolite (15\%) & 10.24 & 5.41 & 9.79 & 4.49 & 9.74 & 6.10 \\
\hline Peat + zeolite (30\%) & 9.93 & 5.97 & 10.20 & 6.77 & 10.82 & 6.47 \\
\hline LSD $_{05}$ & 2.23 & 0.87 & 2.35 & 0.40 & 0.74 & 0.13 \\
\hline
\end{tabular}

Table 6. Effect of substrates on content of dry matter in leaves and fruits of tomatoes during vegetation 
The tomatoes grown in peat and peat + zeolite (30\%) substrates accumulated a higher content of chlorophyll compared with the tomatoes grown in the peat + zeolite (15\%) substrate (Table 7). The content of chlorophyll was $10.5 \%$, chlorophyll $b-11.9 \%$ and chlorophyll $a+b-10.9 \%$ higher compared with the leaves of the tomatoes grown in the peat + zeolite $(15 \%)$ substrate. The highest chlorophyll a to $\mathrm{b}$ ratio was established in the leaves of the tomatoes grown in peat. The carotenoid content was almost the same in the leaves of the tomatoes grown in all substrates.

\begin{tabular}{llllll}
\hline \multirow{2}{*}{ Substrate } & \multicolumn{4}{l}{ Photosynthetic pigment content and ratio, $\mathbf{m g}^{-1}$ fresh mass } \\
\cline { 2 - 6 } & chlorophyll a & chlorophyll b & chlorophyll a + b & $\begin{array}{l}\text { chlorophyll } \\
\text { a to b ratio }\end{array}$ & carotenoids \\
\hline Peat & 1.17 & 0.47 & 1.63 & 2.54 & 0.33 \\
\hline Peat + zeolite (15\%) & 1.05 & 0.42 & 1.47 & 2.50 & 0.30 \\
\hline Peat + zeolite (30\%) & 1.16 & 0.47 & 1.63 & 2.47 & 0.32 \\
\hline LSD $_{05}$ & 0.21 & 0.07 & 0.27 & 0.24 & 0.07 \\
\hline
\end{tabular}

Table 7. Effect of peat and mixture of peat and zeolite substrates on photosynthetic pigment content and the chlorophyll a to $\mathrm{b}$ ratio in leaves of tomato

Zeolite had effect on yield earliness (Figure 12). During the first month of fruiting it ranged from $7.0 \mathrm{~kg} \mathrm{~m}^{-2}$ to $8.0 \mathrm{~kg} \mathrm{~m}^{-2}$ (depending on the substrate). The highest early yield was obtained while growing tomatoes in the peat + zeolite $(15 \%)$ substrate. It was $11.1 \%$ higher compared with the tomatoes grown in peat alone and $14.3 \%$ higher than that obtained from the tomatoes grown in the peat + zeolite (30\%) substrate (insignificant differences). The total yield was higher in the plants grown in peat and zeolite substrates. The extra yield depended on the amount of zeolite in peat. The yield of the tomatoes grown in the peat + zeolite (15\%) substrate was $10.3 \%$ (significant difference) higher than that of the tomatoes grown in the peat substrate alone. This effect was related with zeolite's property to accumulate and retain and then release the nutrients to the plants in due time. However, the admixture of higher amounts of zeolite to the substrate had practically no effect on the tomato yield.

The tomatoes grown in different substrates formed the same number of fruits in a truss. In all treatments the number of fruits per truss was between 4.40 and $4.44 \mathrm{u}$. However, the average fruit mass was slightly different between the treatments and ranged from $133.2 \mathrm{~g}$ to $138.1 \mathrm{~g}$ (Figure 13). The largest were the fruits of the tomatoes grown in the peat + zeolite $(15 \%)$ substrate: their mass was $1.9 \%$ higher compared with the tomatoes grown in peat only and $3.7 \%$ higher than tomato fruits in the peat + zeolite (30\%) substrate (insignificant differences).

The admixture of zeolite into the peat substrate had influence on the biochemical composition of the tomato fruits (Table 8). The fruits of the tomatoes grown in peat-zeolite substrates accumulated less sugars, ascorbic acid and soluble solids. The admixture of zeolite into the peat substrate resulted in a $17.8-19.6 \%$ higher titratable acidity amount (significant difference) 
compared with the tomatoes grown in peat. In addition, they accumulated a slightly higher amount of carotenoids.

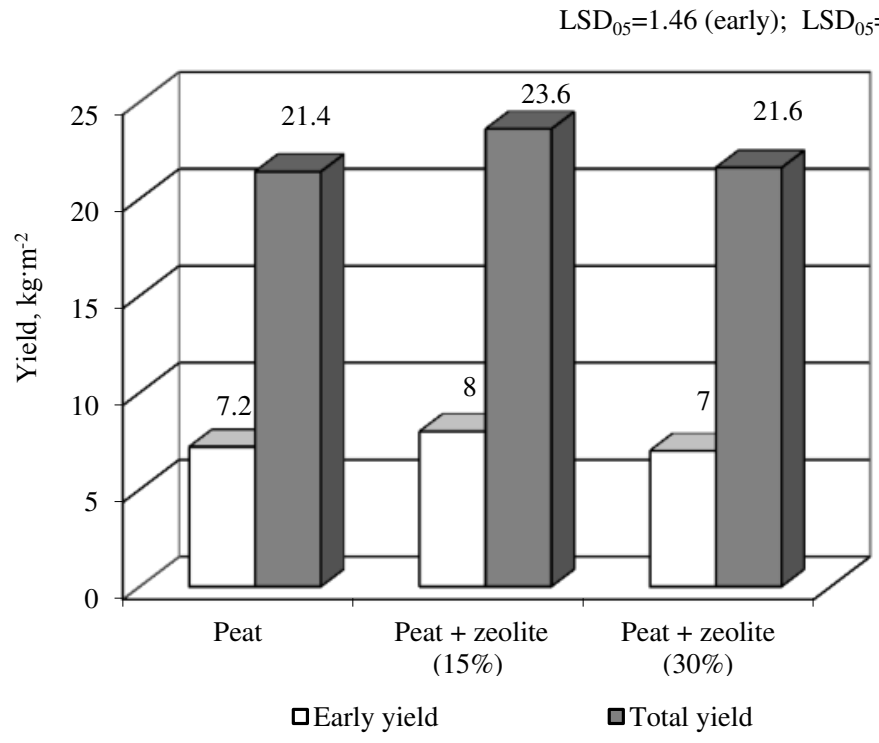

Figure 12. Effect of substrates on early and total yield of tomatoes

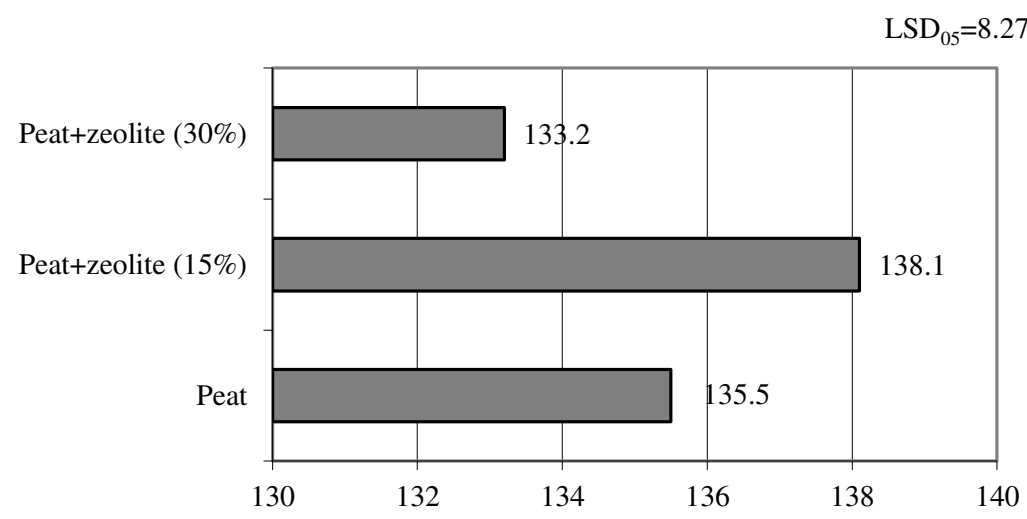

Average fruit mass, $\mathrm{g}$

Figure 13. Effect of substrates on average fruit mass of tomatoes 


\begin{tabular}{cccccc}
\hline Substrate & Sugar, $\%$ & $\begin{array}{c}\text { Dry soluble } \\
\text { solids, } \%\end{array}$ & $\begin{array}{c}\text { Ascorbic acid, } \\
\mathbf{m g} \%\end{array}$ & $\begin{array}{c}\text { Titratable acidity, } \\
\text { \% }\end{array}$ & Carotene, mg\% \\
\hline Peat & 5.03 & 5.2 & 22.0 & 0.56 & 5.5 \\
\hline Peat+zeolite (15\%) & 4.91 & 5.1 & 17.0 & 0.67 & 5.7 \\
\hline Peat+zeolite (30\%) & 4.71 & 4.9 & 18.2 & 0.66 & 0.02 \\
\hline LSD $_{05}$ & 0.98 & 0.4 & 1.8 & 0.6 \\
\hline
\end{tabular}

Table 8. Effect of peat and mixture of peat and zeolite substrates on biochemical composition of tomato fruits

\section{Discussion}

\subsection{Effect of rockwool and coconut fiber substrates on productivity, physiological processes and quality of tomato}

Results of most scientists researches showed that substrates had a significant effect on the plant growth, composition of leaf, total yield and fruit quality [27,31,42,43]. Researchers from different countries analysed the suitability of coco substrates (coconut dust, coco fiber and its mixtures) for growing of vegetables in greenhouses. Data of Lopez et al. [44] showed substrate of coconut dust is proper for growing of tomatoes in greenhouses. It is also characterised as substrate with higher qualities than Canadian peat. Researches of other scientists proved substrates of coconut fiber may be used as organic substrate for growing of plants [4]. In other researches coco substrates was compared to other substrates used in greenhouse vegetablegrowing. There was analysed yield of plants while growing vegetables in coco substrate, perlite, rockwool, sawdust, rise husks [12,44-47]]. Coconut fiber was compared to substrate which is produced from waste composting 48]. Alifar et al. [49] investigated the effect of five different growing media for cucumbers' growing. Results showed that the largest stem diameter, the highest biomass were obtained in cocopeat and perlite-cocopeat media. Fecondini and others [50] data reveal hybrid more than substrate where plants were grown in had more influence for phenological observations and biometric parameters of tomatoes. Our data showed the tomatoes grown in rockwool and coconut fiber grow evenly, height of the plants did not differ a lot.

In our research, physiological processes in tomatoes grown in coconut fiber substrate were similar to that were grown in rockwool. Increasing sap water flow, decreased diameter of stem and bigger difference of leaves and air temperatures showed that more intense transpiration was in tomatoes grown in coconut fiber substrate than in plants grown in rockwool (Figure 8 and 9). It may be assumed this had an influence for non-uniform fruit growth in this substrate compared to rockwool (Figure 10). According to physiological researches' data it may be stated that absorption of substrates of coconut fiber and rockwool for water is different.

The content of carotenoid and chlorophyll pigments in the vegetables depend on growing conditions as well as on variety of vegetable [51,52]. According to Islam at al. [53] data there was no difference between content of chlorophyll and dry matter in the leafs of tomatoes grown 
in coconut fiber and rockwool substrates. There also was no difference on the amount of ascorbic acid in the fruits of tomatoes in these substrates. Our data showed the tomatoes grown in rockwool accumulated more dry matters and pigments of photosynthesis than those grown in coconut fiber substrate.

Various data show substrate has an influence on the yield of tomatoes. Some researches showed yield of tomatoes grown in coconut fiber substrates was higher than grown in other substrates, another researches did not show any difference in the yield [12,48,54]. Kobryn [55] stated bigger yield was got growing tomatoes in rockwool than in substrate Cocovita which is made of coconut palms straw. Jensen's [45] research show there are no fundamental differences between the yield of tomatoes grown in different substrates (perlite, rockwool, coconut, etc.). Carrijo et al. [56] researches state tomatoes grown in coconut substrate were more fertile than those grown in sawdust. Halman [28] data show yield of cherry tomatoes grown in coconut and rockwool was similar. The tomatoes were grown in rockwool, peat, coconut fiber with a different admixture of chips. According to research data, the significantly highest total yield of plants was found in the case of plants grown in peat and in coconut fiber with a higher content of chips in relation to rockwool [57]. Our data showed the yield of tomatoes grown in coconut fiber was little bit higher than those grown in rockwool.

Most scientists found the type of substrate affected the quality of tomato fruit $[28,48,58]$. Selection of substrate has an influence not only on the yield of plants but on quality of the fruits as well as its beginning of yielding [59]. Growth, yield and fruit quality of tomato grown in coconut fiber were not different from those grown in rockwool [54]. Hallman [28] states the tomatoes grown in cocos substrate had more sugar, acids, there also was less ascorbic acid and licopene. Our data showed growing of tomatoes in rockwool and coconut substrate had an influence on the biochemical composition of fruits (Table 4). Tomato hybrid 'Raissa' grown in rockwool accumulated more sugar, dry soluble solids and dry matter in the fruits but tomatoes grown in coconut fiber accumulated more ascorbic acid. The substrate had no influence on the average mass of a fruit. Our data showed the average mass of fruits was pretty similar growing tomatoes both in coconut fiber and rockwool.

\subsection{Effect of peat and peat-zeolite substrates on productivity and quality of tomato}

Zeolite and coco substrates may be used in two ways: first, it may be used as a part of mixture of substrates, second, it may be used as only substrate for vegetable growing. There were researches done analyzing growth of tomatoes in mixed perlite and zeolite substrates, mixing both in different ratios [60,61]. According to data, better results were achieved growing tomatoes in zeolite and perlite substrates (ratio 1:1) than growing in cocos and perlite substrates [33]. There also was analyzed the influence of zeolite mixed with other substrates for peppers', lettuce and various flowers yield as well as productivity $[15,26,62]$. Russian scientists results show lettuce grown in peat and zeolite substrates had smaller content of nitrates, there was bigger yield of cucumbers. Growing vegetable in zeolite substrate there was lower use of fertilizers [20,63]. Our data showed the admixture of zeolite into a peat substrate did not have significant influence for growth of plants. The tomatoes grown in peat and zeolite substrates were a little bit lower than those plants grown in peat. 
Seeking for better evaluation of the influence of mixtures of substrates on the plants growth, there was found content of photosynthetic pigments in the leafs of tomatoes. The content of chlorophyll in the leafs of the plant is one of potential productivity indicators. It is often used aiming to find how any of the growing ways or environmental conditions affect the photosynthesis system of the plants. If growing conditions are inadequate, concentration of chlorophylls and ratio of chlorophylls a to $b$ decreases. For the process of photosynthesis chlorophyll $\mathrm{a}$ is more important as it reacts to changing conditions of the environment rather $[64,65]$. Our data found differences between a chlorophyll content in the leafs ot tomatoes grown in different substrates. The smallest content was in the leaves of tomatoes grown in peat + zeolite $(15 \%)$ substrate. Tomatoes grown in peat + zeolite $(30 \%)$ substrate and peat only accumulated the same content of chlorophylls. Highest ratio of chlorophylls a to $b$ was in the leaves of tomatoes grown in peat substrate. To sum up, positive impact of zeolite for synthesis of pigments of photosynthesis was not found.

Most researches found mixing of zeolite into other substrate has an influence on the quality of fruits. Aghdak et al. [66] in a study based on the effect of various substrates on qualitative properties of sweet pepper found that addition of zeolite to substrate improves quality of sweet pepper fruits. According to Angelis and other [67] results tomato fruit quality was affected only by tomato variety and not by substrate. Other data showed that no significant differences were found between type of substrate on the amount of total soluble solids, sugars and ascorbic acid in fruits of tomatoes [43,55]. Fecondini et al. [50] data showed hybrid but not the substrate plants were grown in had bigger impact for the yield of tomatoes. Our analysis showed that the content of titratable acidity was bigger in the fruits of tomatoes grown in peat-zeolite substrates.

According to different researchers, the admixture of zeolite into a peat substrate has positive influence on the yield of vegetables [14,68]. Ashraf [69] states, after admixture of zeolite into perlite and pumice not only the features of substrate improves but also the yield of tomatoes increases. Jankauskienè at al. [70] data show, growing of seedlings in peat-zeolite substrate had an influence on the quality of the seedlings though it did not have positive influence on the yield of these vegetables. It is important ratio of zeolite and other substrates, its size of fractions [23,71]. Berar et al. [72] data show after admixturing $25 \%$ zeolite into substrate there was found the biggest yield of tomatoes. Živković and others [73] reported admixturing zeolite into peat there was found 35\% bigger yield of tomatoes, though the yield in the trials after admixturing $20 \%$ and $30 \%$ zeolite was the same. Cativelo [23] found more suitable substrate for growing of plants is admixtured substrate with 3-7\% of zeolite compared to substrate which has $15 \%$ zeolite. Roses were grown in zeolite and perlite substrates mixed in different ratio. The biggest number of roses was picked and its quality was the best when roses were grown in zeolite and perlite substrate when ratio was $25: 75$ [74]. Our data showed smaller amount of zeolite in peat (15\%) had bigger impact for yield of tomatoes and average mass of fruit. After admixturing bigger amount of zeolite into peat substrate (30\%), the yield of tomatoes was not bigger but in the leafs of tomatoes there were accumulated more dry matters. 


\section{Conclusions}

1. The content of dry matter and photosynthetic pigments in tomato leaves depended on the substrate: the tomatoes grown in rockwool accumulated higher dry matter and chlorophylls in leaves than those of tomatoes grown in coconut fiber substrate. The intensity of photosynthesis depended on the hybrid of tomato. Photosynthesis intensity of tomato hybrid 'Admiro' was more intensive in rockwool and photosynthesis intensity of hybrid 'Raissa' - in coconut fiber substrate. Tomato transpiration was intensive in both substrates, but small stem increase in 24 hours showed insufficient supply of water for plants. This delayed fruit growth in day, especially of these tomatoes, which were grown in coconut fiber substrate. The yield of tomatoes grown in coconut fiber substrate was bigger than this one of tomatoes grown in rockwool. The ascorbic acid content in tomatoes fruit which were grown in coconut fiber was higher than in fruit of tomatoes grown in rockwool.

2. Plants grown in peat-zeolite substrates were lower. The admixture of zeolite into a peat substrate did not influence significantly dry matter accumulation in tomato leaves. The highest chlorophyll a to $\mathrm{b}$ ratio was in the leaves of tomatoes grown in peat substrate. Thus, the positive effect the admixtures of zeolite into peat substrate on synthesis of photosynthetic pigments were observed.

Admixture of zeolite into peat substrate affected the volume of the yield and the average fruit mass. The yield of tomatoes grown in peat + zeolite $(15 \%)$ substrate was the highest. The tomatoes grown in peat + zeolite $(15 \%)$ substrate recorded the highest average fruit mass. The tomatoes grown in peat-zeolite substrates accumulated less sugar, ascorbic acid, soluble solids, however, higher amount of titratable acidity and carotenoids.

\section{Author details}

Julė Jankauskienė*, Aušra Brazaitytė and Pranas Viškelis

*Address all correspondence to: j.jankauskiene@lsdi.lt

Institute of Horticulture, Lithuanian Research Centre for Agriculture and Forestry, Lithuania

\section{References}

[1] Verdonck O, De Vleeschauwer D, De Boodt M. The influence of the substrate to plant growth. Acta Horticulturae 1982;126 251-258.

[2] Olle M, Ngouajio M, Siomos A. Vegetable quality and productivity as influenced by growing medium: a review. Žemdirbystè=Agriculture 2012;99(4) 399-408. 
[3] Bhat NR, Suleiman MS, Thomas B, Lekha VS, George P, Ali IS. Growing substrates for organic lettuce production in Kuwait. World Journal of Agricultural Sciences 2013;9(2) 143-147.

[4] Evans MR, Kondoru S, Stamps RH. Source variation in physical and chemical properties of coconut coir dust. HortScience 1996;3 965-967.

[5] Noguera P, Abad M, Noguera V, Puchades R, Maquieira A. Coconut coir waste, a new and viable ecologically-friendly peat substitute. Acta Horticulturae 2000;517 279-286.

[6] Yau PY, Murphy RJ. Biodegraded cocopeat as a horticultural substrate. Acta Horticulturae 2000;517 275-278.

[7] Rahimi Z, Aboutalebi A, Zakerin A. Comparison of different medium for production of Sweet pepper transplant. International Research Journal of Applied and Basic Sciences 2013;4(2) 307-310.

[8] Shishko AA. The use of coconut fiber in greenhouse. Vegetable Growing. Scientific works 2006;12 187-192.

[9] Blom TJ. Coco coir versus granulated rockwool and 'arching' versus traditional harvesting of roses in a recirculating system. Acta Horticulturae 1999; 481 503-510.

[10] Nogurea P, Abad M, Puchades R, Noguera V, Maquieira A, Martinez J. Physical and chemical properties of coir waste and their relation to plant growth. Acta Horticulturae 1997;450 365-373.

[11] Prasad M. Physical, chemical and biological properties of coir dust. Acta Horticulturae 1996;450 21-29.

[12] Carrijo OA, Vidal MC, dos Reis NVB, de Souza RB, Makishima N. Tomato crop production under different substrates and greenhouse models. Horticultura Brasileira. 2004;22(1) 5-9.

[13] Ghehsared AM, Hematian M, Kalbasi M. Comparison of date-palm wastes and perlite as culture substrates on growing indices in greenhouse cucumber. In: The 1th International and the 4th National Congress on Recycling of Organic waste in agriculture 26-27 April 2012, Isfahan, Iran.

[14] Albaho M, Thomas B, Isathali S, George P, Ghloum D. Alternative growing media for growbag tomato production in Kuwait. Acta Horticulturae 2014;1037 1087-1091.

[15] Harland J, Lane S, Price D. Further experiences with recycled zeolite as a substrate for the sweet pepper crop. Acta Horticulturae 1999;481 187-196.

[16] Stamatakis M, Koukouzas N, Vassilatos CH, Kamenou E, Samantouros K. The zeolites from evros region, Northern Greece: a potential use as cultivation substrate in hydroponics. Acta Horticulturae 2001;548 93-104. 
[17] Postnikov AV, Zekunov AV, Eliseev NA. Vegetable growing in zeolite. Agricultural Chemistry 1991;11 22-25.

[18] Ming DW, Mumpton FA. Natural zeolites'93: Occurrence, properties, use. International Committee on Natural Zeolites, Brockport, New York;1995.

[19] Mumpton FA. La roca magica: Uses of natural zeolites in agriculture and industry. Proceedings of the National Academy of Sciences of the United States of America 1999;96 3463-3470.

[20] Perfilieva VF. Use of natural zeolites in greenhouses. The use of zeolites from Siberia and the Far East in agriculture 1988 77-80.

[21] Perfilieva VF. Natural zeolites for vegetable growing. Agricultural Chemistry 1991;12 77-79.

[22] Loboda BP, Yakovleva NN. The use of zeolite substrates in greenhouses. Agricultural Sciences. 1999;5 18-19.

[23] Cattivello C. Use of substrates with zeolites for seedling vegetable and pot plant production. Acta Horticulturae 1995;401 251-258.

[24] Manolov I, Antonov D, Stoilov G, Tsareva I, Baev M. Jordanian zeolite tuff as a raw material for the preparation of substrates used for plant growth. Journal Central European of Agriculture 2005;6(4) 485-494.

[25] Demir H, Polat E, Sonmez I, Yilmaz E. Effects of different growing media on seedling quality and nutrient contents in pepper (Capsicum annuum L. Var longum cv. Super Umut F1). Journal of Food Agriculture and Environment 2010;8(3ann 4) 894-897.

[26] Gül A, Eroğul D, Ongun AR. Comparison of the use of zeolite and perlite as substrate for crisp-head lettuce. Scientia Horticulturae 2005;106 464-471.

[27] Peyvast GH, Noorizadeh M, Hamidoghli J, Ramezani-Kharazi P. Effect of four different substrates on growth, yield and some fruit quality parameters of cucumber in bag culture. Acta Horticulturae 2007;742 175-182.

[28] Hallman E, Kobryń J. Yield and quality of cherry tomato (Lycopersicon Esculentum Var. Cerasiforme) cultivated on rockwool and cocofiber. Acta Horticulturae 2003;614 693-697.

[29] Gao HB, Zhang TJ, Lv GY, Zhang GH, Wu XL, Li JR, Gong BB. Effects of different compound substrates on growth, yield and fruit quality of cucumber. Acta Horticulturae 2010;856 173-180.

[30] Gruda N. Do soilless culture systems have an influence on product quality of vegetables? Journal of Applied Botany and Food Quality 2009;82 141-147.

[31] Padem H, Alan R. The effect of some substrates on yield and chemical composition of pepper under greenhouse conditions. Acta Horticulturae 1994;366 445-451. 
[32] Alekseeva TP, Perfilieva VF, Krinitsyn GG. Organomineral fertiliser with prolonged action based on peat. Chemistry of plant raw materials 1999;4 53-59.

[33] Traka-Mavrona E, Gerasopoulos D, Pritsa T, Maloupa E. Growth, fruit yield and quality of tomato in relation to substrate and nutrient source in a soilless culture system. Acta Horticulturae 2001;548 173-180.

[34] Wettstein D. Chlorophyll Letale und der submikroskopishe Formweschsel der Plastiden. Experimental cell research 1957.

[35] Ton Y. Basics of phytomonitoring. Phytomonitoring. 1996;1 3-5.

[36] Ton Y, Nilov N, Kopyt M. Phytomonitoring: a new information technology for improving crop production. Acta Horticulturae 2001;562 257-262.

[37] Helrich K., editor. AOAC: Official methods of analysis.15 $5^{\text {th }}$ ed. Arlington, VA; 1990.

[38] Davies BH. Carotenoids. In: Goodwin TW. (ed.) Chemistry and Biochemistry of Plants Pigments, vol. 1. London, New York: Academic Press; 1996.

[39] Metodiniai nurodymai nitratams nustatyti augalininkystės produkcijoje. Vilnius; 1990.

[40] Food analysis: general techniques, additives, contaminants and composition. Rome: FAO; 1986.

[41] Tarakanovas P, Raudonius S. Agronominių tyrimų duomenų statistinė analizė taikant kompiuterines programas ANOVA, STAT, SPLIT-PLOT iš paketo SELEKCIJA ir IRRISTAT. Akademija; 2003.

[42] Olympious CM. Soiless media under protected cultivation rockwool, peat, perlite and other substrates. Acta Horticulturae 1993;323 215-234.

[43] Peyvast GH, Olfati JA, Kharazi PR, Roudsari ON. Effect of substrate on greenhouse cucumber production in soilless culture. Acta Horticulturae 2010;871 429-436.

[44] Lopez F, Castillo GAB, Torres JLT, Castillo FS. Hydroponic culture of tomato with coconut coir dust as substrate, and its response to ammonium and potassium. Agrociencia 1996;30 495-500.

[45] Jensen MH, Rorabaugh PA, Garcia AM. Comparing five growing media for physical characteristics and tomato yield potential. Proc. of Am. Soc. Plasticulture 1998;27 31-34.

[46] Urrestarazu M, Salas MC, Mazuela P, Ventura F, Castellano D, Sanchez JA. Effect of forced aeration on certain parameters of crop tomato by substrate culture. Acta Horticulturae 2000;659 679-683.

[47] Inden $\mathrm{H}$, Torres $\mathrm{A}$. Comparison of four substrates on the growth and quality of tomatoes. Acta Horticulturae 2004; 644 205-210. 
[48] Urrestarazu M, Salas MC, Mazuela P. Methods of correction of vegetable waste compost used as substrate by soilless culture Acta Horticulturae 2003;609 229-233.

[49] Alifar N, Ghehsareh AM, Honarjoo N. The effect of growth media on cucumber yield and its uptake of some nutrient elements in soilless culture. Journal of Science and Technology of Greenhouse Culture 2010;1(1) 19-25.

[50] Fecondini M, Mezzetti M, Orsini F, Gianquinto G, Poppi S. Zeolites in media mixes for soilless production: first results on tomato. Acta Horticulturae 2011;893 1007-1012.

[51] Kobayashi K, Tsurumizu A, Toyoda M, Saito Y. Contents of chlorophyll, b -carotene and pesticide residues in butter head lettuce produced by various cultivation methods. Nippon Shokuhin Kogyo Gakkaishi 1989;36 676-681.

[52] Kimura M, Rodriguez-Amaya DB. Carotenoid composition of hydroponic leafy vegetables. Journal of Agricultural and Food Chemistry 2003;51(9) 2603-2607.

[53] Islam MS, Khan S, Ito T, Maruo T, Shinohara Y. Characterization of the physicochemical properties of environmentally friendly organic substrates in relation to rockwool. Journal of Horticultural Science and Biotechnology 2002;77 143-148.

[54] Shinohara Y, Hata T, Maruo T, Hohjo M, Ito T. Chemical and physical properties of the coconut-fiber substrate and the growth and productivity of tomato (Lycopersicon Esculentum Mill.) plants. Acta Horticulturae 1999;481 145-150.

[55] Kobryn J. The effect of substrate type on the yield and quality of tomato fruits (Lycopersicon Esculentum Mill.) in glasshouse cultivation. Folia horticulturae 2002;14(1) 53-59.

[56] Carrijo OA, Liz RS, Makishima N. Fiber of green coconut shell as an agricultural substrate. Horticultura Brasileira 2002;20(4) 533-535.

[57] Kleiber T, Markiewicz B, Niewiadomska A. Organic substrates for intensive horticultural cultures: yield and nutrient status of plants, microbiological parameters of substrates. Polish Journal of Environmental Studies 2012;21(5) 1261-1271.

[58] Tzortzakis NG, Economakis CD. Impacts of the substrate medium on tomato yield and fruit quality in soilless cultivation. Horticultural Science 2008;35 83-89.

[59] Lopez J, Vásquez F, Ramos F. Effect of substrate culture on growth, yield and fruit quality of the greenhouse tomato. Acta Horticulturae 2004;659 417-424.

[60] Ymeri A, Gerasopoulos D, Maloupa E. Quality characteristics of 'Daniela' tomatoes grown on a perlite-zeolite culture bag fed with slow release fertiliser. Acta Horticulturae 1999;491 331-336.

[61] Savvas D, Samantouros K, Paralemos D, Vlachakos G, Stamatakis M, Vassilatos C. Yield and nutrient status in the root environment of tomatoes (Lycopersicon Esculen- 
tum) grown on chemically active and inactive inorganic substrates. Acta Horticulturae $2004 ; 644$ 377-383.

[62] Mohammad MJ, Karam NS, Al-Lataifeh NK. Response of croton grown in a zeolitecontaining substrate to different concentrations of fertilizer solution. Communications in Soil Science and Plant Analysis 2004;35(15-16) 2283-2297.

[63] Makhalov AV. The use of zeolites for growing cucumbers in greenhouses. The use of zeolites from Siberia and the Far East in agriculture 1988 83-86.

[64] Hay RKM., Andrew JW. An introduction to the physiology of crop yield. New York: Jonh Wiley and Sons. Inc.;1989.

[65] Gabryś H, Kacperska A, Kopcewicz J, Lewak S, Starck Z, Strzałka K, Tretyn A. Podstawy fizjologii roślin. Warszawa: Wydawnictwo Naukowe PWN;1998.

[66] Aghdak P, Mobli M, Khoshgoftarmanesh A. Effect of various culture media on apparent and qualitative properties of sweet pepper cv. 'Emili'. 1st National Congress on Hydroponic and Greenhouse Product 2002.

[67] Angelis G, Papadantonakis N, Spano T, Petrakis C. Effect of substrate and genetic variation on fruit quality in greenhouse tomatoes: preliminary results. Acta Horticulturae 2001;548 497-502.

[68] Markovic V, Takac A, Ilin Z. Enriched zeolite as a substrate component in the production of pepper and tomato seedlings. Acta Horticulturae 1995;396 321-328.

[69] Ashraf S. The effect of different substrates on the vegetative, productivity characters and relative absorption of some nutrient elements by the tomato plant. Advances in Environmental Biology 2011;5(10) 3091-3096.

[70] Jankauskienė J, Brazaitytė A. The influence of various substratum on the quality of cucumber seedlings and photosynthesis parameters. Sodininkystė ir daržininkystė $2008 ; 27(2)$ 285-294.

[71] Djedidi M, Gerasopoulos D, Maloupa E. The effect of different substrates on the quality of Carmello tomatoes (Lycopersicon esculentum Mill.) grown under protection in a hydroponic system. Cahiers Option Mediterranéennes 2003;31 379-383.

[72] Berar V, Poşta Gh. Research concerning the zeolites influence, used in the culture substratum, upon the quality of greenhouse grown tomato. Journal of Horticulture, Forestry and Biotechnology 2011;15(4) 45-47.

[73] Živković C, Kokot J, Mojić S, Rabrenović D. A preliminary study on the effect of the natural clinoptilolite and bentonite additions on the tomato "Nemo Netta" growth. In: Proceedings of the 5th Serbian-Croatian-Slovenian Symposium on Zeolites. May 30th - June 2nd, 2013, Serbia. http://www.zds.org.rs/doc/Proc_148-150.pdf (accesed 8 September 2014). 
[74] Maloupa E, Samartzidis C, Couloumbis P, Komninou A. Yield, quality and photosynthetic activity of greenhouse-grown 'Madelon' roses on perlite-zeolite substrate mixtures. Acta Horticulturae 1999;481 97-102. 